\title{
The discourse of generational segmentation and the implications for postgraduate medical education
}

\author{
Jamiu O. Busari
}

Published online: 16 April 2013

(C) The Author(s) 2013. This article is published with open access at Springerlink.com

\begin{abstract}
The growing demands for easily accessible, cost effective and efficient health care services are hindering many medical training programs in delivering well prepared physicians, equipped with the competencies to tackle new and complex health care problems. In addition to this, many medical institutions are finding it difficult to design curricula that would prepare today's physicians adequately for the ongoing changes in health care. Targeted customer service is a growing phenomenon in health care, where healthcare institutions are operating as retail service providers, design experiences and deliver care around the convenience of consumers rather than the preferences of providers. Gradually finding its way into medical education, this concept entails investing in understanding the beliefs and values of consumers as a result of their different expectations and differences. Defined by the experiences that create common values among the members of a specific group, the discourse of generation segmentation has proven to be a helpful way of understanding consumer differences. There are four known generations currently impacting the pattern and distribution of healthcare services and in the coming decade, the future of medical education In this paper, medical education is re-examined in the light of this phenomenon of generation segmentation and whether today's physicians are being effectively prepared to practice in a fast changing world. The analysis provided in this paper presents a recommendation for the medical curriculum of a new millennium based on the changing needs and expectations of different generations of consumers.
\end{abstract}

J. O. Busari (ه)

Medical Residency Program, Department of Pediatrics, Atrium Medical Center,

Henri Dunantstraat 5, 6401 CX Heerlen, the Netherlands

email: j.busari@atriummc.nl

\section{J. O. Busari}

Department of Educational Development and Research, Faculty of Health, Medicine and Life Sciences, University of Maastricht, P. O. Box 616, 6200 MD Maastricht, the Netherlands 
Keywords Generation - Postgraduate medical education - Physicians - Training · Health care

\section{Introduction}

Health care delivery and health professions education are at major crossroads in many countries today. It is thought that due to increased demands for easily accessible and cost-effective health care services, today's practising physicians and those in training may no longer be capable of delivering the sort of care 21st century patients (would) need [1]. Also, with the current pace and increasing complexity of the changes in health care, it is becoming increasingly difficult for care providers to effectively manage the health care needs of their communities [1]. Each year, it is estimated that about one million physicians are trained in more than 2,000 medical schools and an estimated $\$ 100$ billion/year is spent on health professions education globally. In addition, the average cost of tuition for each graduate medical student is set at approximately $\$ 113,000 /$ year with unit costs being highest in North America and lowest in China [2].

In North America and Europe, the average time spent in medical training to become specialist physicians is between 5 and 7 years, in addition to the 3-5 years spent in undergraduate medical school. The past few years have, however, witnessed a rethinking of current training practices and many think that the duration of the medical training is too long. They argue that medical training programmes can be shortened considerably without any serious consequences to the outcome of the programmes. It is thought that by fostering attention on the essential content of the programmes and forcing educational institutions to eliminate unnecessary and repetitious material in the curriculum, an average of 14 years of training (running through college to the speciality fellowship period) could significantly be reduced by approximately 4 years. Bearing in mind that the average medical student in the United States graduates with an estimated $\$ 160,000$ in debt, 4 years less of medical school would be significant in lowering tuition debts of trainees [3].

\section{The discourse of generational segmentation}

While the pressures on health care systems and the costs of care are rising, new challenges to the traditional system of health care delivery are also emerging. New stakeholders are entering the business of health care in many countries, disrupting and redefining how health care can be accessed [4]. Health care has also turned into a consumer market where patients, i.e. the consumers, have found ways to navigate the complexities of various health care systems by comparing service, quality, and costs of care [5]. As a result, health care institutions are operating as retail service providers, designing experiences and delivering care around the convenience of consumers rather than the preferences of providers. They have also had to invest in understanding the beliefs and values of the consumers they serve because of their 
different expectations from the health care system, i.e. targeted consumer services [6]. This phenomenon of 'targeted customer service' in health care is a growing concept within medical education and it is expected to influence and shape the future training of physicians considerably.

Gaining increasing popularity around the mid-1990s, the concept of generation segmentation has proven to be a helpful means of understanding consumer differences and how knowledge of this can be used to provide specific services. Although defining 'generations' is not an exact science (as the breakdown is subjective and generalized), marketers and journalists use these groupings in targeting their marketing to particular age groups. There is the tendency for disagreement about the time frames covered by the generations, the names given to them and probably over-generalizations of the personalities. Nonetheless, generations can be defined by the experiences that create common values among the members of a specific group. There are four generations that have been identified as currently impacting the pattern and distribution of a number of services that includes the health care system, namely the Greatest Generation, the Baby Boomers, the Gen Xers, and the Millennials [7-9].

\section{The four generations}

The members of the Greatest Generation-1925-1944-went through the Great Depression and served during World War II. Characterized by duty and sacrifice, the Greatest Generation value credentials as an indication of expertise. They generally accept authority and tend to follow society's rules. The Baby Boomers1945-1964 - on their part grew up amidst great prosperity and believe that they can change the world. They experienced the Civil Rights movement, the Vietnam War, and the sexual revolution. Unlike the Greatest Generation, Boomers have a history of challenging traditional institutions and values. They feel that institutions have failed to handle societal needs responsibly and believe that rules are to be followed only if they can deliver the goods, if not 'they are made to be broken, or modified'. The Gen Xers-1965-1984-grew up in a difficult time socially and financially. While their Boomer parents were striving for self-fulfilment and monetary success, they were often 'latch key' children. Gen Xers trust themselves and their peers rather than corporations and are described as the most self-sufficient and sceptical generation. They are considered the most loyal employees and flatly reject the Boomers workaholic approach. They invest loyalty in a person rather than an establishment. Finally, the Millenials/Gen Yers-1985-2005-are considered to be the most threatened and protected generation in history. Compared with previous generations, Millennials are excessively insulated with an unprecedented amount of parental supervision and advocacy. They are collaborative, tolerant, and comfortable with speed and change, they feel at home with multi-tasking and multiple forms of electronic/digital media. Their perception of life and world events has been formed through the lens of digital technology, e.g. personal computers and Smartphones [10].

(Table 1) provides an overview of how technology, health care and consumer markets have been influenced by the phenomenon of generational segmentation. 


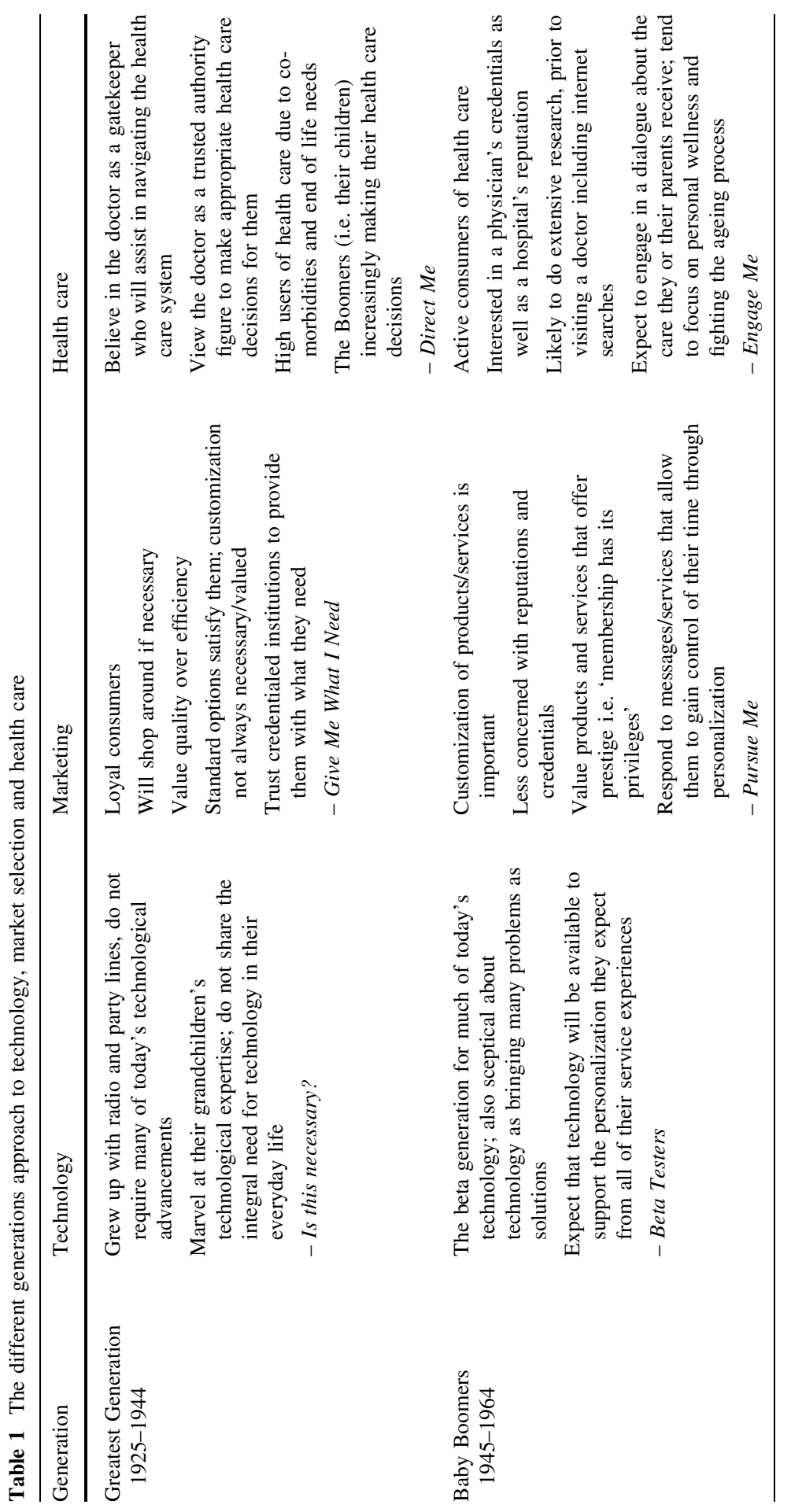




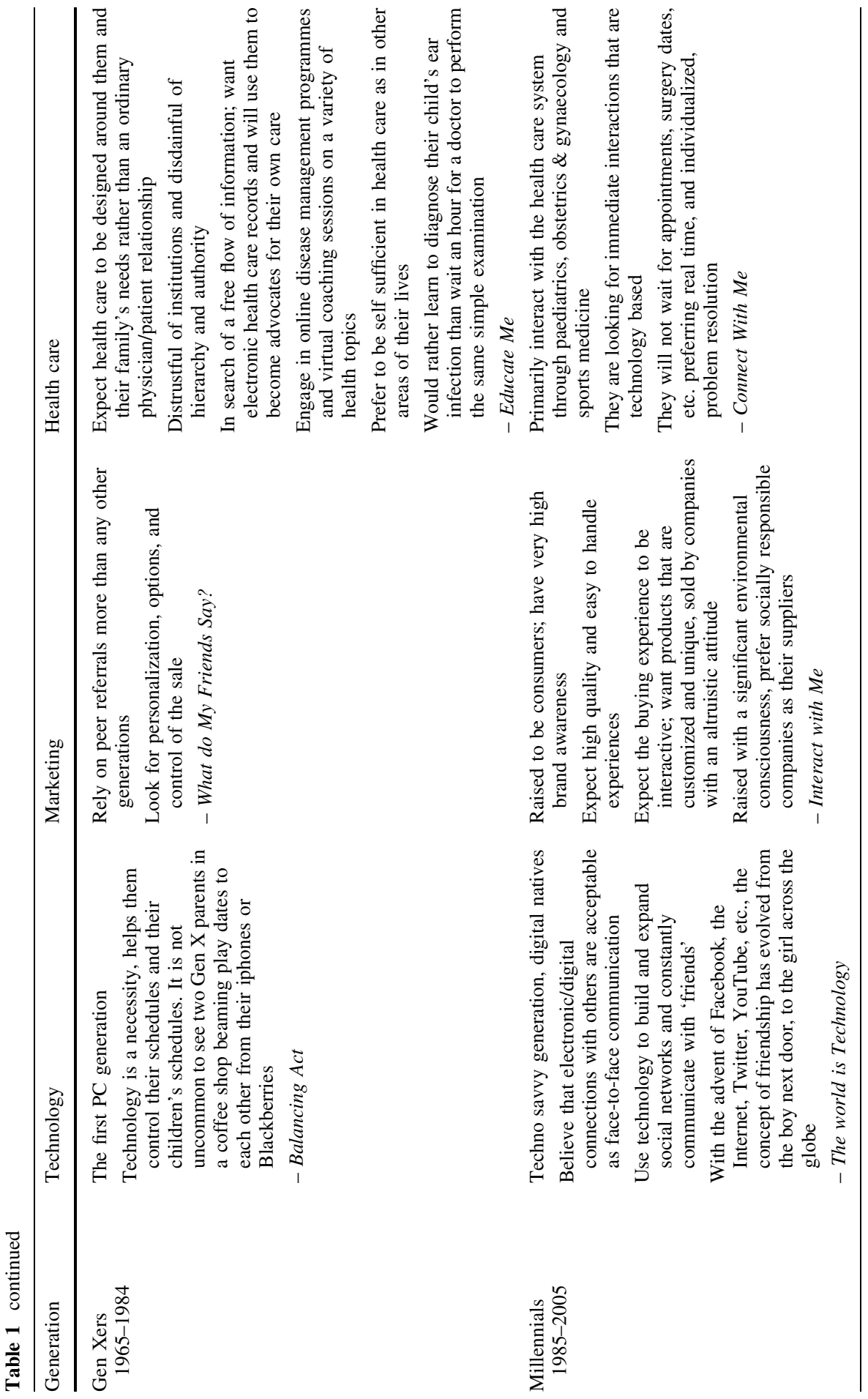




\section{Generational segmentation and medical education}

Regardless of generation, consumers expect quality, continuity and easy access to good health care. Decisions about hospital and care providers, however, are influenced by their generational experiences. According to the Thomson-Reuters Pulse Survey, Boomers often selected physicians based on hospital affiliation. Gen Xers and Millennials on the other hand rely on recommendations from friends and family. The Greatest Generation and Boomers were the least likely to switch physicians while Millennials and Gen Xers, were likely to switch their primary care physician due to service experiential factors such as lack of confidence, relationship satisfaction, location of service facility and waiting times [7]. A Deloitte health care customer survey in 2009 showed that $16 \%$ of their respondents had switched physicians in the last year, with 2 out of 3 switching because of dissatisfaction with the service they received'[5]. For Gen Xers and Millennials service is a critical retention tool for physicians.

So what do the observed trends in generation segmentation mean for the way physicians of the future should (and need to) be trained? Similar to the different behaviours towards health care, consumer markets and the use of technology, the different generations demonstrate peculiar attitudes towards education. While members of the Greatest Generation revere the institution of education as the source of all knowledge, conform to rules and regulations and tend to experience having failed if and when feedback is offered, members of the Millennial generation, and to a lesser degree the Gen Xers, thrive on immediate and continuous feedback, feel insecure without it and expect to be acknowledged based on how big their social network followers are. Furthermore, members of this group increasingly turn to channels outside the traditional educational establishment for the source of their information and knowledge. Baby Boomers on their part question the legitimacy of authority feeling that the source of reliable knowledge or information begins and ends with them. They would happily stick to jotting notes on paper rather than use a 'savvy and fault prone' ipad tablet and they are the ones who tend to populate the category of 'late adopters' when it comes to utilizing modern technology (Table 2).

The discourse of generational gaps and its impact on the training of physicians also provides a different perspective for the ongoing transitions in (postgraduate) medical education. Similar to initiatives in health care and marketing, awareness of the phenomenon of generational segmentation and how it defines the behaviour of members within the different generations can and should be used in understanding the educational needs of the 'Millennial' physician in training [10]. It should be applied in defining how future medical curricula need to be designed so that they match the growing and changing health care needs in society. Especially when the expectation is that by the year 2030, an increase in the number of Gen Xers and Millennial patients, and to a lesser degree Baby Boomers, would cause a change in the demand and utilization of health care services. These changes are already forcing health care professionals to change the way they work. 
Table 2 The different generations relationship with (medical) education

\begin{tabular}{|c|c|c|c|c|}
\hline $\begin{array}{l}\text { Educational } \\
\text { characteristic }\end{array}$ & $\begin{array}{l}\text { Greatest } \\
\text { Generation } \\
1925-1944\end{array}$ & $\begin{array}{l}\text { Baby Boomers } \\
1945-1964\end{array}$ & $\begin{array}{l}\text { Gen X'ers } \\
1965-1984\end{array}$ & $\begin{array}{l}\text { Millennials } \\
1985-2005\end{array}$ \\
\hline Authority & $\begin{array}{l}\text { Conformers, } \\
\text { authority } \\
\text { rules } \\
\text { Command and } \\
\text { control }\end{array}$ & $\begin{array}{l}\text { Usually } \\
\text { uncomfortable } \\
\text { with authority } \\
\text { figures } \\
\text { Question } \\
\text { legitimacy of } \\
\text { authority }\end{array}$ & $\begin{array}{l}\text { Comfortable with } \\
\text { authority } \\
\text { Not intimidated by } \\
\text { authority }\end{array}$ & $\begin{array}{l}\text { Believe respect must be } \\
\text { earned } \\
\text { Question authority }\end{array}$ \\
\hline $\begin{array}{l}\text { Signs of } \\
\text { respect }\end{array}$ & $\begin{array}{l}\text { Revere } \\
\text { authority/ } \\
\text { superiors } \\
\text { Give special } \\
\text { treatment }\end{array}$ & $\begin{array}{l}\text { Revere } \\
\text { authority/ } \\
\text { superiors } \\
\text { Give special } \\
\text { treatment }\end{array}$ & $\begin{array}{l}\text { Demand authority } \\
\text { Expect to be held in } \\
\text { esteem } \\
\text { Expect to be listened } \\
\text { to based on earned } \\
\text { professional/ } \\
\text { academic } \\
\text { achievement }\end{array}$ & $\begin{array}{l}\text { Demand authority } \\
\text { Expect to be held in esteem } \\
\text { Expect to be listened to } \\
\text { based on the number of } \\
\text { contacts/followers in } \\
\text { network e.g. Twitter, } \\
\text { Facebook }\end{array}$ \\
\hline $\begin{array}{l}\text { Source of } \\
\text { knowledge }\end{array}$ & $\begin{array}{l}\text { Personal } \\
\text { experiences } \\
\text { Storytelling } \\
\text { Trial and error }\end{array}$ & $\begin{array}{l}\text { Books and } \\
\text { libraries } \\
\text { Microfilms } \\
\text { Experts/ } \\
\text { intellectuals } \\
\text { Experiments }\end{array}$ & $\begin{array}{l}\text { Electronic media, } \\
\text { E-books } \\
\text { CD ROMs } \\
\text { Online information/ } \\
\text { databases }\end{array}$ & $\begin{array}{l}\text { WWW, Wikipedia } \\
\text { Google, You Tube } \\
\text { Social networks }\end{array}$ \\
\hline $\begin{array}{l}\text { Favoured } \\
\text { learning } \\
\text { approach }\end{array}$ & Apprenticeship & $\begin{array}{l}\text { Lectures } \\
\text { Pen and paper } \\
\text { Slides/overhead } \\
\text { sheets }\end{array}$ & $\begin{array}{l}\text { Emails } \\
\text { PowerPoint } \\
\text { presentations }\end{array}$ & $\begin{array}{l}\text { Simulations } \\
\text { (Serious) gaming } \\
\text { You Tube instructions } \\
\text { Virtual teaching on the web }\end{array}$ \\
\hline $\begin{array}{l}\text { Reaction to } \\
\text { feedback }\end{array}$ & $\begin{array}{l}\text { May feel } \\
\text { insulted by } \\
\text { continuous } \\
\text { feedback }\end{array}$ & $\begin{array}{l}\text { May feel } \\
\text { insulted by } \\
\text { continuous } \\
\text { feedback }\end{array}$ & $\begin{array}{l}\text { Feel at home with } \\
\text { feedback } \\
\text { Not dependent on } \\
\text { immediate and } \\
\text { continuous } \\
\text { feedback }\end{array}$ & $\begin{array}{l}\text { Thrive on immediate and } \\
\text { continuous feedback } \\
\text { Feel insecure without } \\
\text { feedback }\end{array}$ \\
\hline Key value & Feeling valued & Feeling valued & Feeling valued & Feeling valued \\
\hline
\end{tabular}

Box 1 Characteristics of the Millennial physician

Expert in the science of medicine and the (interrelationships between) social sciences and humanities related to clinical care

Skilled in communications, care giving and interpersonal relationships including patient advocacy and cultural sensitivity

Is a professional, including being ethical and functioning as a member or leader of a team

Life-long learner, able to reflect and evaluate self, and improving based on practice, experience and feedback

Knowledgeable about the health care system, including the principles of economics, public health, management, quality assurance and patient safety 


\section{Conclusion}

In conclusion, the changing trends in health care continue to pose new challenges for the way health care is currently organized and the way physicians would need to be trained. As physicians increasingly have to work with other professionals in health care teams or integrated care systems, the education of physicians would have to be modified to match the desires and values in a new community of health consumers $[11,12]$. Based on these insights on generational differences, there is going to be a need for a new sort of physician (the 'Millennial physician'), with a different set of skills and competencies than the current medical training programmes offer (Box 1). The duration of medical training would also need to be shorter than it currently is, due to increased costs involved with the training and from the redundancies currently being witnessed in many training programmes. The medical curriculum that would be needed would be one that focuses on developing more general, collaborative and community-specific competencies in physicians and made up of linear and modular rotations that are combined in remote settings, far from the mother institution. Finally, the end product of the training programmes, i.e. the Millennial physician, would be the digital native practitioner who can easily navigate his way through the vast array of web-based, electronic and mobile technology using these not only as a major means of communication, but also as the primary access to (medical) information and resources on the web.

Open Access This article is distributed under the terms of the Creative Commons Attribution License which permits any use, distribution, and reproduction in any medium, provided the original author(s) and the source are credited.

\section{References}

1. Bohmer RM, Lawrence DM. Care platforms: a basic building block for care delivery. Health Aff (Millwood). 2008;27(5):1336-40.

2. Frenk J, Chen L, Bhutta ZA, et al. Health professionals for a new century: transforming education to strengthen health systems in an interdependent world. Lancet. 2010;376(9756):1923-58.

3. Emanuel EJ, Fucks VR. Shortening medical training by $30 \%$. JAMA. 2012;307(11):1143-4.

4. Christensen CM, Bohmer R, Kenagy J. Will disruptive innovations cure health care? Harv Bus Rev. 2000;78(5):102-12.

5. Keckley P, Eselius L. 2009 Survey of Health Care Consumers: key findings, strategic implications. Delloite Center for Health Solutions. Washington DC: Deloitte LLP; 2009. p. 1-17.

6. Porter ME. What is value in health care? N Engl J Med. 2010;363(26):2477-81.

7. MacCracken L, Pickens G, Wells M. Matching the market: using generational insights to attract and retain consumers. Thomsom Reuters Research brief: Thomson Reuters; 2009. p. 1-13.

8. Howe M, editor. The new generation gap: impact on healthcare. Forum for healthcare strategists; 2008. Scottsdale, Arizona.

9. GMC. Tomorrow's doctors: outcomes and standards for undergraduate medical education; 2009.

10. Stanton SW. Decoding generational differences: fact, fiction...or should we just get back to work? Talent Market Series: Deloitte LLP; 2008. p. 1-112.

11. Shine KI. Crossing the quality chasm: the role of postgraduate training. Am J Med. 2002;113(3): 265-7.

12. IOM. Crossing the quality chasm: a new health system for the 21 st century. Washington, DC: National Academy Press; 2001. 


\section{Author Biography}

Jamiu Busari is an associate professor of medical education at Maastricht University and the clinical director of the pediatric residency training program at the Atrium Medical Centre, Heerlen the Netherlands. His research interests include residency training, curriculum development and management and leadership development in residents. 